\title{
ENCALYPTA SECT. RHABDOTHECA IN RUSSIA ENCALYPTA SECT. RHABDOTHECA В РОССИИ
}

\author{
VLADIMIR E. FEDOSOV ${ }^{1}$ \\ ВЛАДИМИР Э. ФЕДОСОВ ${ }^{1}$
}

\begin{abstract}
Molecular phylogenetic analysis of the Encalypta sect. Rhabdotheca in Russia based on the chloroplast $\operatorname{trn} \mathrm{L}-\mathrm{F}$ region reveals that "eperistomate E. rhaptocarpa", an entity of dubious status, represents one of the most isolated entities, thus requiring recognition as a separate species. The earliest validly published name for this species is likely E. pilifera Funck, 1819, and E. intermedia Juratzka, 1870 is apparently its synonym. Description and illustrations of the former species, based on Russian specimens, are provided. Comments on the distribution of other species of the section are provided and all species are mapped. Encalypta spathulata was found to be heterogeneous, but at the same time it is the most isolated among all other studied species. The specific status of $E$. trachymitria has also been confirmed. Encalypta vulgaris is the most heterogeneous among Russian species of the section, both in $\operatorname{trn} \mathrm{L}-\mathrm{F}$ sequences and morphology. In Russia, it has mainly European distribution.
\end{abstract}

Резюме

Согласно данным анализа последовательностей $t r n \mathrm{~L}-\mathrm{F}$ хлоропластной ДНК видов рода Encalypta из секции Rhabdotheca, представленных образцами из России, “бесперистомная E. rhaptocarpa" оказалась наиболее изолированной и заслуживает видового статуса. Приоритетным названием для этого вида является E. pilifera Funck, 1819, a E. intermedia Juratzka, 1870 - ее синонимом. Приводятся описание и иллюстрации E. pilifera по образцам из России. Для других видов из секции Rhabdotheca, встречающихся в России, даны карты и комментарии к распространению. Показана гетерогенность Encalypta spathulata, которая, в то же время, является наиболее хорошо изолированной из всех изученных видов. Подтвержден видовой статус $E$. trachymitria. Из всех видов секции, встречающихся в России, Encalypta vulgaris наиболее гетерогенна и по последовательностям $\operatorname{trn} \mathrm{L}-\mathrm{F}$, и по морфологическим признакам; в России этот вид встречается главным образом в европейской части.

KEYWORDS: Encalyptaceae, Encalypta rhaptocarpa-complex, Encalypta sect. Rhabdotheca, mosses, Russia, $\operatorname{trn} \mathrm{L}-\mathrm{F}$

\section{INTRODUCTION}

The genus Encalypta was revised worldwide by Horton $(1982,1983)$ who accepted 19 species and 4 subspecies. Among them, she segregated the Encalypta rhaptocarpa - E. vulgaris complex (hereafter, the E. rhaptocarpa-complex), a group of species corresponding to Encalypta sect. Rhabdotheca Müll.Hal.

The taxonomy of this species complex is difficult due to high variation of most characters and a great number of combinations of character states. Due to these reasons, the group includes many species of ambiguous status, while widespread and \pm worldwide accepted species intergrade, posing problems with their delimitation. At the same time, no one special revision of this complex has been published so far. Hagen (1910) discussed variation of some taxa within the E. rhaptocarpa complex, considering most of them as separate species. On the other hand, Lawton (1971) treated most taxa of this group with- in E. vulgaris Hedw. Horton in her revision of Encalyptaceae (Horton, 1979a,b, 1982, 1983) specially addressed mainly American taxa of this complex, accepting E. armata Broth., E. asperifolia Mitt., E. vittiana Horton, E. flowersiana Horton, E. spathulata Müll.Hal., but provided only a general discussion on the widespread and most variable species, E. intermedia Ripart, E. rhaptocarpa Schwägr., and E. vulgaris Hedw. For these species Horton provided diagnostic characters, with discussion on intergradations between typical phenotypes. In addition, she listed 26 species names, and 48 infraspecific combinations "believed to apply to problematic taxa in the section Rhabdotheca [that is, those taxa that are not comprehensively treated in the present publication, including E. rhaptocarpa, E. vulgaris and E. intermedia]".

After Horton revision, a number of new species were described in this complex: E. sinica J.-C. Zhao \& M. Li, E. texana Magill, E. obovatifolia Nyholm, E. buxbau-

\footnotetext{
1 - Department of Geobotany, Biological Faculty, Moscow State University, Leninskie Gory, Moscow 119234 Russia - Poccия 119234, Москва, Ленинские горы, Московский государственный университет, Биологический факультет, каф. геоботаники; e-mail: fedosov_v@mail.ru
} 
mioidea T.Cao, C.Gao \& X.L.Bai, E. thianschanica J.C. Zhao, R.-L. Hu \& S. He (Magill, 2006, Nyholm, 1996, Cao et al., 2001). Mogensen revised E. rhaptocarpa var. leptodon Lindb. and accepted it as a good species E. trachymitria Ripart. The question with delimitation of common species in E rhaptocarpa - E. vulgaris complex, however was not discussed.

Four species from the E. rhaptocarpa-complex were reported from the territory of Russia (Ignatov et al., 2006), including E. spathulata and E. trachymitria, the specific status of which is not accepted by some authors. Ignatov \& Ignatova (2003) noted that eperistomate $E$. rhaptocarpa apparently represents a separate taxon and considered the problem of its correct name, although neither suggesting any existing species name, nor describing it as a new one. Being poorly delimited in morphological characters, an attempt to apply DNA markers to its study is reported here.

\section{METHODS AND MATERIAL}

Preliminary tests for different molecular markers, including nrITS \& 5.8rRNA gene and trnT-D, found them to be heterogeneous. Cloned trnT-D sequences have very low variation in the studied group, while ITS were too variable for unequivocal aligning, including one case of two specimens of one species, which were not possible to align. Thus, the present analysis is based only on trnL-F sequences. The sampling was focused on representation of geographically distant populations of all species of the E. rhaptocarpacomplex in Russia: E. rhaptocarpa (both with and without peristomes), E. spathulata, E. trachymitria and E. vulgaris. One specimen revealed during revision of herbaria data and identified as E. intermedia Jur. (from Anabar Plateau) was also incorporated into the analysis. Among the sequenses compared, 20 are original. Specimen data and GenBank accession numbers are given Table 2 . The origin of sequenced specimens of ingroup taxa is indicated with stars on maps of corresponding species. The protocol of DNA extraction and amplification was the same as in Gardiner et al. (2005). Sequences were aligned manually. We performed parsimony ratchet analysis with NONA (Goloboff, 1994) within the Winclada (Nixon, 1999a) shell. A multi-ratchet option with five sequential parsimony ratchet runs was used (Nixon, 1999b). The trees were rooted on E. streptocarpa Hedw., which represents the most isolated section in the genus (Horton, 1983).

Haplotype network analysis was performed in TCS 1.21 (Clement et al., 2000) with gap coding as a single event irrespective of their length with the connection limit at 10 steps $(95 \%)$.

Specimens in LE, MW, MHA, KPABG, PTZ and SYKO were revised.

\section{RESULTS}

The strict consensus tree from the MP analysis resolved species of the section Rhabdotheca in a clade with 100 bootstrap support (Fig. 1). This terminal clade represents a polytomy of smaller clades and separate sam- ples. Three taxa, "eperistomate E. rhaptocarpa", E. thachymitria and E. rhaptocarpa were resolved as separate clades. The former is called E. pilifera in Figs. 1-2, based on the following discussion. Bootstrap analysis revealed moderate support only for E. pilifera (71) and low support for E. rhaptocarpa (59). Encalypta vulgaris was not found to be monophyleric. Its two most western samples (Smolensk and France) and two SE European (Rostov and Bashkiria) formed separate clades, the latter having high support (89). Population of E. vulgaris from Mongolia was found to be unrelated to any others. Encalypta spathulata samples were found in an unresolved polytomy. TCS haplotype analysis found E. rhaptocarpa and E. pilifera in the opposite ends of one net (Fig. 2), which also includes E. trachymitria and E. vulgaris. E. spathulata is too distant and formed its own net. Two specimens of $E$. trachymitria from Urals and Caucasus were found to be identical, while 4 specimens of $E$. vulgaris appeared to be quite diverse, which is similar to the results of the MP analysis.

As "eperistomate E. rhaptocarpa" turns out to be monophyletic and more distant from $E$. rhaptocarpa than E. vulgaris and E. trachymitria, it has to be considered as a separate species, unless E. vulgaris and E. rhaptocarpa are considered to be synonymous. A specimen, previously identified as E. intermedia Jur. from the Anabar Plateau was also found in this clade. The species status of E. trachymitria is confirmed by trnL-F identity of specimens of different origin (although only two were sequenced). Likewise, E. spathulata, being heterogeneous itself, strongly differs from all other studied taxa by specific motifs, thus it obviously should be treated as a separate species. At the same time, E. vulgaris was found not to be genetically homogeneous, however, in the TCS network shown it is not mixed with other haplotype groups. In addition, $E$. vulgaris is usually morphologically distinct enough to be accepted as a species. Thus, five species of the section are accepted here for Russian territory.

\section{NOMENCLATURE}

The problem with the name for the eperistomate $E$. rhaptocarpa for a long time was solved by referring plants without a peristome to E. spatulata or E. rhaptocarpa var. leptodon, as the absence of the peristome was used in keys as the main difference of the latter taxa from $E$. rhaptocarpa (cf. Limpricht, 1895; Savich-Lyubitskaya \& Smirnova, 1970). However, Horton (1983) very clearly described the distinction of E. spathulata from E. rhaptocarpa, and later Mogensen (2001) demonstrated that E. rhaptocarpa var. leptodon is not an eperistomate taxon. Thus, eperistomate E. rhaptocarpa appeared lacking an appropriate name, and bryologists who do not believe in its identity with $E$. rhaptocarpa simply call them 'peristomate rhaptocarpa' and 'eperistomate rhaptocarpa', adding sometimes that the latter likely deserves species status.

A search among earlier names reveals E. pilifera (Funck, 1819), description and carefully done illustra- 


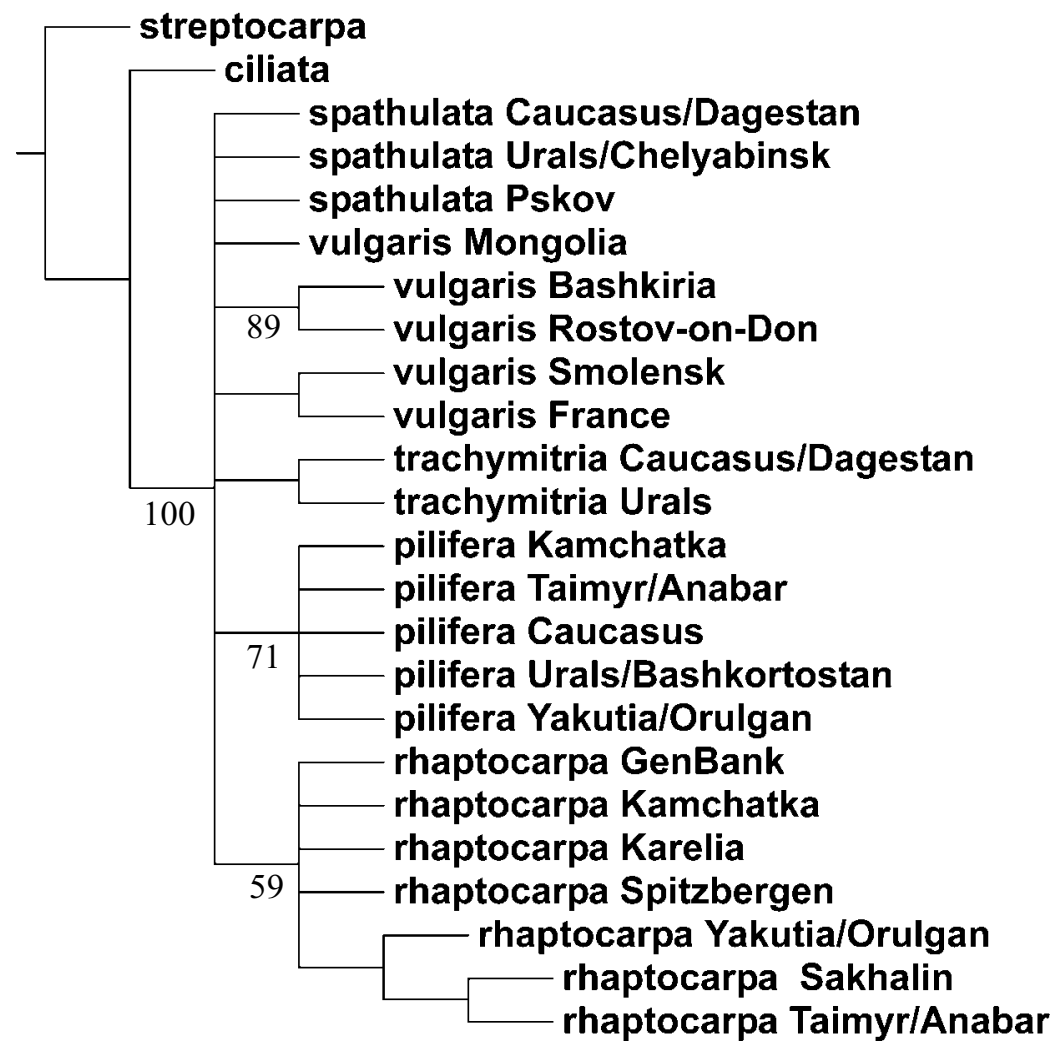

Fig. 1. Strict consensus tree of 1758 trees found in MP ratchet analysis of trnL-F sequences. Bootstrap supports above 50 calculated for 2000 iterations are shown below branches.

tions of which demonstrate its congruence with what has been recently understood as 'eperistomate rhaptocarpa' in all mportant details, including ribbed capsules, vestigial peristome and piliferous leaves. Later, it was reduced to a variety, but remarkably, of as much as four species: E. extinctoria var. pilifera (Funck) Hartm., E. leptodon var. pilifera (Funck) Lindb., E. rhabdocarpa var. pilifera (Funck) Nees \& Hornsch., and E. vulgaris var. pilifera (Funck) Huebener. As an infraspecific taxon it was treated by Podpera (1954) for Europe and Savicz-Lyubitskaya \& Smirnova (1970) for Soviet Union territory, and later largely ignored in check-lists.

There is an incongruence in the literature about the peristome presence in this taxon. Being eperistomate, it has been described as having peristome by e.g. Limpricht (1895) and Savicz-Lyubitskaya \& Smirnova (1970).

Encalypta pilifera Funck in Sturm, Deutschl. Fl., Abt. II, Cryptog. 17: [7]. 1819. Type: Germany "Berneck und Stein" (not seen).

Figs. 3, 4.

Plants green to yellowish green or brownish in lower part, in loose to compact tufts at base brown-tomentose. Stems short, 0.2-0.8 cm, \pm branched, in transverse section triangular to circular, central strand absent to weakly differentiated. Leaves incurved to slightly twisted when dry, erect to spreading when wet, larger toward the apex,
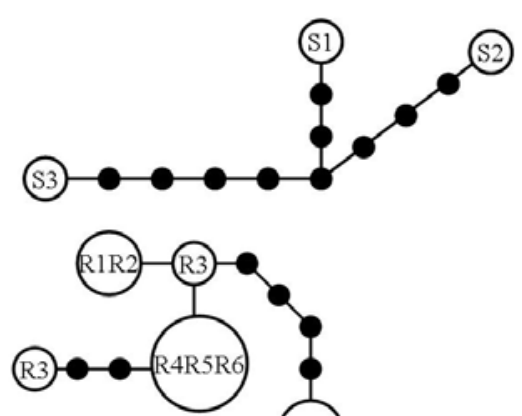

Fig. 2. TCS haplotype network. Specimen abbreviation is given in Table 2 (page 112). Missing haplotypes are shown as solid dots. oblong-lanceolate to lingulate in lower part of stem, ovatelanceolate to ovate in upper part, (1.6-)1.8-2.2(-2.4) ×0.3$0.5 \mathrm{~mm}$, plane, concave to keeled distally; apices obtuse, acute to short-acuminate, mucronate to hair-pointed, costa strong, shiny, golden or reddish-brown (in xeric environments), ending few cells below apex, percurrent to long-excurrent, in transverse section semicircular, concave abaxially, with \pm strong stereid band, 1-2 layers of large thin-walled cells and adaxial epidermis composed of papillose cells similar to those of leaf lamina, proximally (in zone of smooth rectangular cells) costa composed of uniform large cells with scarcely differentiated stereid band; lamina unistratose; margins plane, mostly 1-stratose, in upper part unclearly serrulate due to protruding papillae; laminal cells subquadrate to hexagonal, 10-15(-18) $\times 10-12 \mu \mathrm{m}$, with $2-5 \mathrm{c}$-shaped papillae per cell; basal cells rectangular, (28-)33-48(-52) $\times 12-20$ $\mu \mathrm{m}$, smooth; transition from papillose upper cells to smooth basal cells gradual; basal juxtacostal cells with longitudinal walls thin and transverse walls thickened, yellowish to orange, basal marginal cells with uniformly thickened walls, \pm distinctly differentiated, in 2-4(-5) rows narrower, 40-70×10-14 $\mu \mathrm{m}$, greenish. Autoicous. Seta 2$7 \mathrm{~mm}$, reddish brown, erect to slightly curved. Capsule cylindric or spindle-form, straight, inclined to curved, 


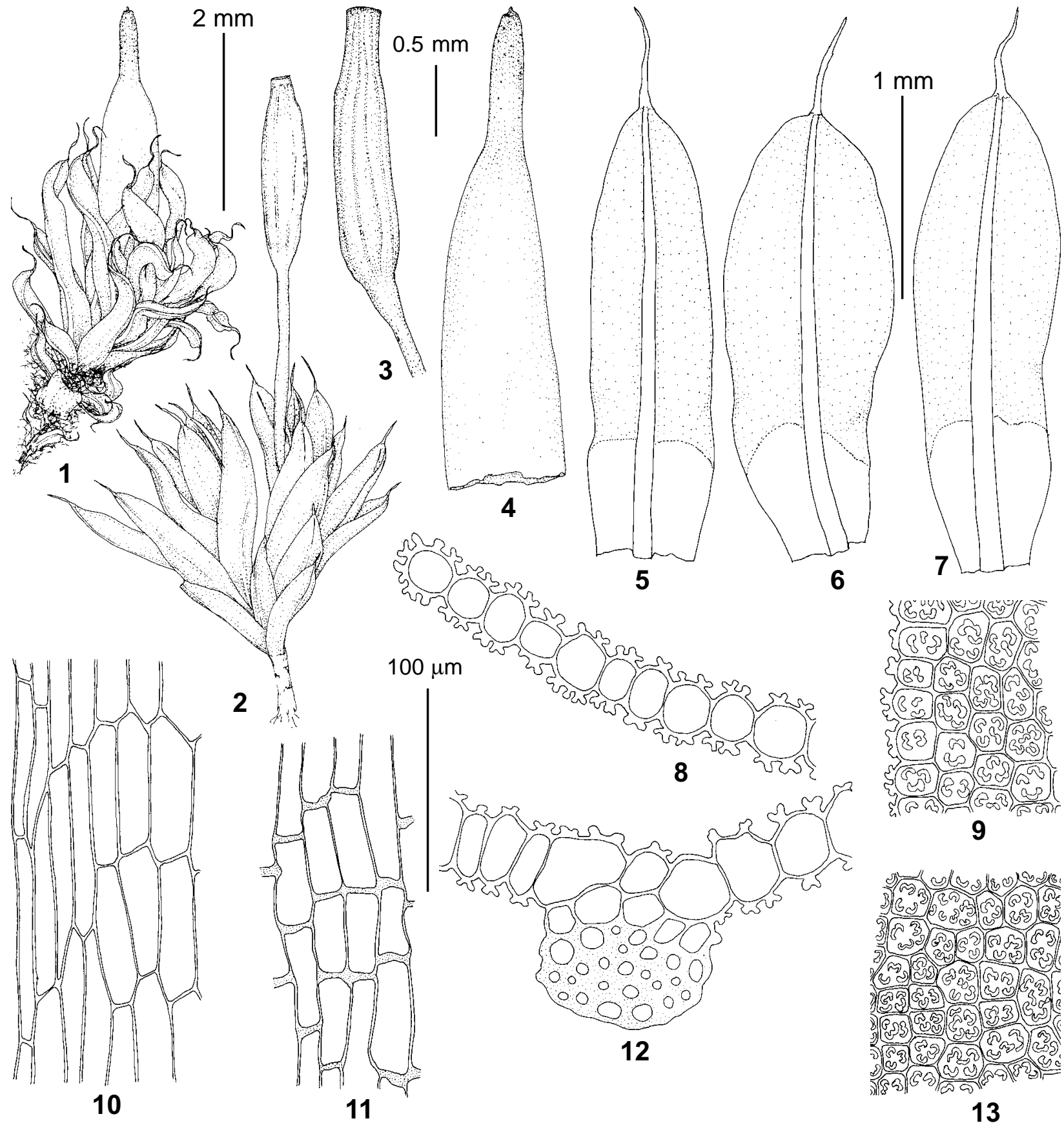

Fig. 3. Encalypta pilifera Funck (from Russia, Kamchatka, Esso, 20.VIII.2003, Czernyadjeva \#105, LE): 1 - habit, dry; 2 habit, wet; 3 - capsule; 4 - calyptra; 5-7 - leaves; 8, 12 - leaf transverse sections; 9 - upper laminal cells; 10 - basal marginal cells; 11 - basal juxtacostal cells; 13 - median laminal cells. Scale bars: $2 \mathrm{~mm}$ for 1-2; $1 \mathrm{~mm}$ for 5-7; $0.5 \mathrm{~mm}$ for 3-4; $100 \mu \mathrm{m}$ for 8-13.

1.5-2.5(-3.2) mm, ribbed, green, further brown to brownish red, with dark red rim around mouth, ribs orange to dark red; peristome absent or weakly developed, fallen with operculum, rarer it remains as transparent fragile remnants on the mouth border on few fresh capsules; operculum long-rostrate, to $1.5 \mathrm{~mm}$ long. Calyptra 3-5 $\mathrm{mm}$, extends well below capsules, whitish to golden, entire or eroded at base, smooth or uneven, sometimes papillose distally, distinctly narrowed toward rostrum; rostrum dark, straight to curved, 0.7-1.1 mm, \pm papillose.
Spores yellowish-brown, heteropolar, on proximal view radially plicate, on distal view densely covered with uniform large semicircular papillae, brown, 26-36(-40) $\mu \mathrm{m}$.

DIFFERENTIATION AND VARIATION

The combination of well ribbed eperistomate capsules, entire base and short rostrum of calyptra, and apiculate to hair pointed leaves separates E. pilifera from all other Encalypta species.

Some other characters of the species vary significantly. Costa is usually strong, shiny, golden to brownish or red, 

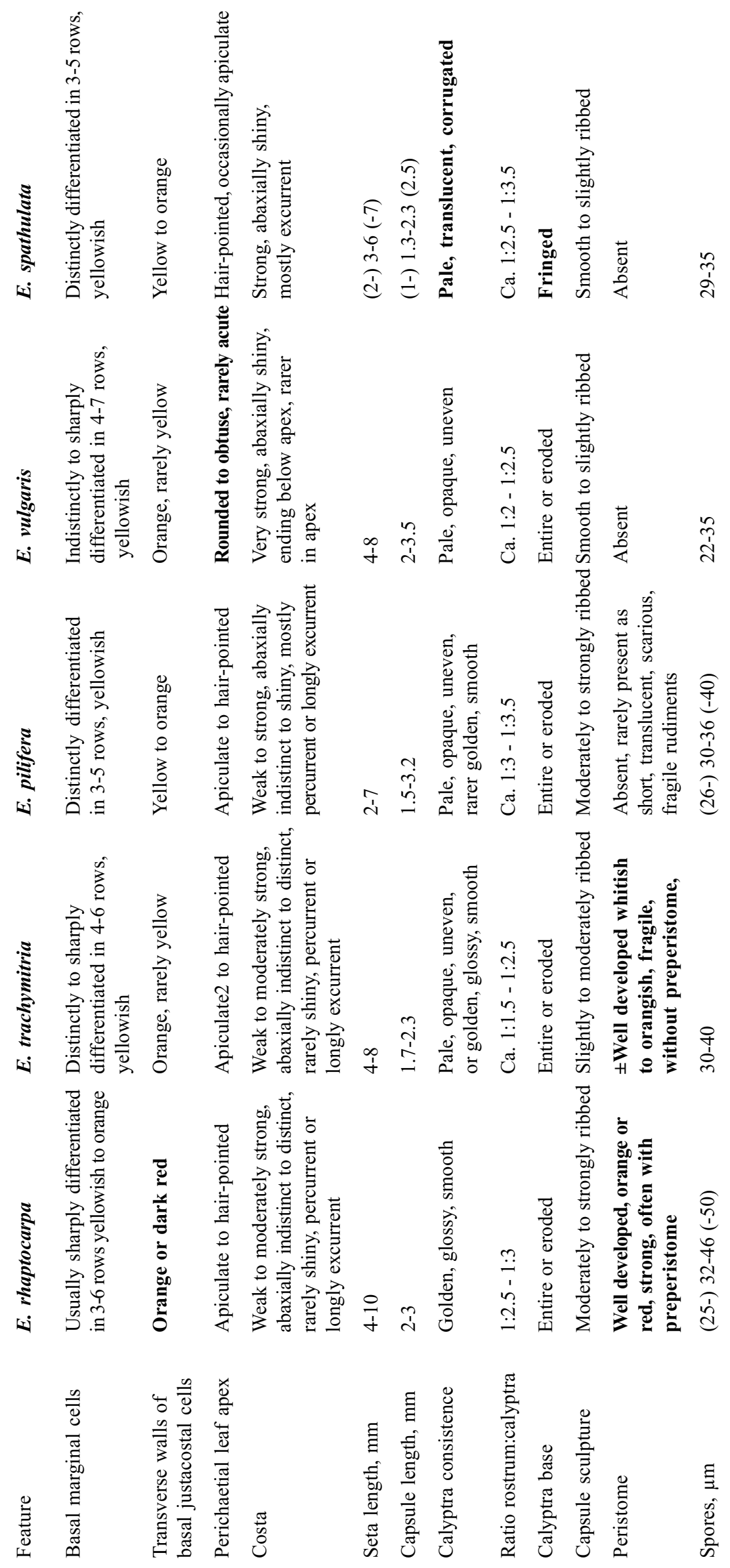
on young leaves green, but in some specimens it is less contrasting in color, looking weaker and not clearly delimited from laminal cells. In Dagestan, Orenburg Province, Mongolia and some other southern regions, $E$. pilifera has some leaves with percurrent costae, appearing as a transitional form to E. vulgaris, which occurs in the same regions. However, sporophytic characters show no intergradation and upper leaves are still apiculate. The seta length varies in Russian specimens from 2 to $8(-10)$ $\mathrm{mm}$ within one region, with all the intergradations between extremes, and generally plants with relatively short setae are associated with more xeric territories.

Typically $E$. pilifera can be easily delimited from $E$. vulgaris by hair-pointed leaves and strongly ribbed capsules. Also the ratio of rostrum length to calyptra length can be useful, being lower in E. pilifera than in E. vulgaris. At the same time in xeric areas, specimens with transitional morphology occasionally occur. Such specimens are relatively not rare in Orenburg Province, Altai and Mongolia. Specimens with weakly keeled apiculate leaves and striate capsules can be referred to E. pilifera, but ones with smooth, single-coloured light capsules and apiculate leaves are questionable, apparently representing hybrids.

Encalypta trachymitria can be confused with $E$. pilifera or with transitional specimens between $E$. pilifera and E. vulgaris due to fragile peristomes, which are broken off in some specimens. In such cases relatively weak costa and weak striae on capsules could be suggestive for specimen identification.

Horton (1983) discussing morphological variation of E. spathulata, noted, that some North American populations of this species have a lightly fringed to eroded calyptra base. Some specimens with eperistomate capsules, smooth calyptrae, less translucent than in typical $E$. spathulata and usually glossy and with straight to eroded base were found in LE, identified/confirmed as $E$. spathulata by Mogensen. All specimens from Russia labeled so in LE were of this sort. In our opinion, they are within the variation of E. pilifera.

PROBABLE SYNONYMS OF E. PILIFERA

Encalypta intermedia Jur., 1870, was described as having eperistomate ribbed capsules (Juratzka \& Milde, 1870), not contradicting to Funck's description of $E$. pilifera. Horton (1983) characterized this species also by short setae, the calyptra reaching the perichaetial leaves, and the relatively short rostrum of calyptrae $(0.8-1.0 \mathrm{~mm})$, but provided no differentiation between this species and E. rhaptocarpa s.1., that can be eperistomate according to the treatment. Magill (2007) synonymized E. intermedia with E. rhaptocarpa without comment, describing the latter as a species with a weak to well developed peristome. In Russian eperistomate specimens with ribbed capsules, the seta is variable in length, and the calyptra usually has a very short rostrum. Specimen that fits Horton's strict circumscription of $E$. intermedia was found in trnL-F analysis with other specimens of "eperistomate E. rhaptocarpa", i.e. E. pilifera.

Encalypta rhaptocarpa var. nuda I. Hagen, 1910. Regarding E. vulgaris and E. rhaptocarpa as two species, Hagen (1910) did not accept eperistomate E. rhaptocar$p a$ at the species level, segregating it into E. rhaptocar$p a$ as var. $n u d a$ I. Hagen. In the original description Hagen noted two characters of var. nuda, different from E. rhaptocarpa s.str.: lacking a peristome and apiculate (but not piliferous) leaf apices. In this respect E. rhaptocarpa var. $n u d a$ also differs from E. pilifera Funck, 1819. From the other hand in E. pilifera specimens from Russia both apiculate and piliferous leaves occur. Most specimens labeled E. rhaptocarpa as var. nuda from Russian territory have piliferous leaves. According to my experience, this character is highly variable in E. pilifera and the full range of intergradation among apiculate, mucronate and piliferous leaves often occurs in one specimen, but perichaetial leaves are always mucronate or piliferous.

Encalypta obovatifolia Nyholm, 1996 has eperistomate ribbed capsules and calyptrae not fringed at the base. Further this species was accepted by Hallingbäck (2008). According to Nyholm, it differs from other taxa within the E. rhaptocarpa complex by plain obovate leaves, large upper laminal cells, $15-22 \mu \mathrm{m}$ and large spores, $39-40(-44) \mu \mathrm{m}$. At the same time, both Juratzka in the description of E. intermedia and Funck in the description of E. pilifera noted that these species differ from $E$. rhaptocarpa in broader leaves. In some specimens from Russia upper leaves occasionally have an obovate form, although this character was found to be quite variable. Spore size also widely varies within E. rhaptocarpa and E. pilifera, occasionally reaching $40 \mu \mathrm{m}$, which is considered as diagnostic for E. obovatifolia. Cell size in $E$. pilifera also varies, mostly increasing in populations from highly humid climates: cells are around $15 \mu \mathrm{m}$ in specimens from xeric and ca. $18 \mu \mathrm{m}$ from humid areas. Thus, cells of 15-22 $\mu \mathrm{m}$ in E. obovatifolia from the suboceanic region of Scandinavia seem to be only partly out of the variation of E. pilifera in Russia. Encalypta obovatifolia was reported as a species restricted to calcareous rocks, i.e. also similar in this respect to E. pilifera. Due to courtesy of L. Hedenäs, I was able to study the photograph of the E. obovatifolia holotype (S), and found no differences from E. pilifera in habit, leaf shape, capsule and calyptra characters.

\section{ECOLOGY}

Encalypta pilifera occurs in conditions and microhabitats similar to those of $E$. rhaptocarpa: on rock outcrops, more rarely on bare soil in tundra, meadows, and steppe communities, etc. It grows more often on calcareous sedimentary rocks (limestone, dolomite, marble), rarer occurring on igneous rocks; it also is not rare on basaltoids and other basic and ultrabasic rocks with relatively high $\mathrm{Ca}$ content, but is never seen on acidic rocks poor in $\mathrm{Ca}$. The preference of rock types varies, being 
stricter in more humid areas and broader in xeric ones. For example, in humid Eastern Kamchatka (Kronotskyj State Reserve) it grows only on calcareous rocks with Gymnostomum aeruginosum Sm., while in a relatively xeric depression among Eastern and Western Ranges in Central Kamchatka, it is relatively frequent in association with such saxicolous species as Encalypta brevicolla (Bruch et al.) Ångstr. and Hedwigia ciliata Hedw. The situation is similar for E. obovatifolia, which is a strongly calciphilic species in Sweden, as described by Hallingbäck (2008).

\section{DISTRIBUTION}

Encalypta pilifera has a wide distribution in Russia, mostly associated with Subarctic, montane areas (Fig. 4). It penetrates to the Arctic only in relatively xeric climatic conditions (Taimyr Peninsula, Chukotka and Vrangel Island). Occasionally, it also occurs in lowland areas with calcareous rock outcrops (Lipetsk and Orenburg Provinces).The species is exceptionally rare or absent in humid areas like Murmansk Province, Karelia, Southern Part of Russian Far East. At the same time, this is the most common species of the section in xeric areas of Eastern Caucasus (Dagestan) and Southern Siberia (Transbaikalia). In Siberia northward (Subarctic Taimyr, Yakutia, Chukotka and Kamchatka) both species, E. pilifera and E. rhaptocarpa s.str., occur. According to my field experience in Taimyr and Kamchatka, E. pilifera generally occupies more xeric and more calcareous habitats, but their ecological preferences overlap and in some cases $E$. pilifera and E. rhaptocarpa grow together. I have not seen any E. pilifera specimens from the Russian high Arctic (north of $75^{\circ}$ ) where E. rhaptocarpa occurs, but Horton's map of E. intermedia indicates that the species penetrates to the high Arctic.

As I believe that $E$. intermedia is not distinct from $E$. pilifera, its distribution in Europe, North Africa, Western Asia given by Horton (1983) is also a part of the range of E. pilifera, as well as xeric areas in Asia from the Middle East eastward to Mongolia. In North America E. pilifera occurs throughout Rockies from Nevada to Southern Alaska and also on xeric areas of Elsmere Island and in North Greenland (Horton, 1983).

Selected specimens examined:

RUSSIA: European Russia: Murmansk Province, Kandalakshskij Coast, Cape Turij, 29.VII.1967, coll. Schljakov \#113 (LE); Lipetsk Province, Donskoj Distr. Galichja Gora, 26.VIII.1962, coll. Samsel' \# 69 (MW); Orenburg Province, Kuvandykskij Distr., Orenburgskij State Reserve, 30.V.2004, coll. Zolotov \& Spirina s.n. (MHA); Urals: Perm Province, Krasnovisherskij Distr., Churochnaja River lower course, 12.VIII.1995, coll. Bezgodov \# 717 (MW); Bashkortostan Republic, Sterlitamak Distr., Shihan Yuractau, 14.VI.2010, coll. Baisheva \# 1641-4 (MW); Caucasus: Karachaevo-Cherkessian Republic, Teberdinskyj State Reserve, 12.IX.2005, coll. Ignatov \& Ignatova \# 05-3738 (MW); Kabardino-Balkarija Republic, 24.VIII.2005, Aktoprak xeric depression, coll. Ignatov, Ignatova \& Kharzinov \# 05-1569 (MHA); Dagestan Republic, Gunib
Distr., Mountain Botanical Garden territory, 20.V.2009, coll. Ignatov \& Ignatova \# 09-747 (MHA); Siberia: Krasnojarsk Territory, Taimyrskyj Distr., Taimyrskyj State Reserve, Ledyanaja Bay vicinity, 23.VII.2004, coll. Fedosov \#Enc2 (MW); Krasnojarsk Territory, Taimyrskyj Distr., Maymecha River valley, 28.VI.2009, coll. Fedosov \# 09-234 (MW); Altai Mts, Kosh-Agach Distr., Oroy Creek upper stream, 30.VII.2008, coll. Seregin \& Seregina \# M-2152 (MW); Burytia Republic, East Sayan Mts, valley of Sorok River, 11.VII.2008, coll. Afonina s.n. (LE); Zabaikal'sky Territory, Agin-Buryat Autonomous Area, National Park Alkhanai, 10.VII.2006, coll. Afonina \#2406 (LE); Yakutia: EvenoBytantaiskij Distr., Orulgan Range, 28.VII.2011, coll. Ignatov \# 11-4058 (MW); Khangalasskij Distr., Lenskie Stolby, 19.VIII.2000, coll. Ignatov \#00-584 (MHA); Indigirka River valley near Tyubelyakh Settl., 29.VI.1976, coll. Afonina s.n. (LE); Ust'-Maja Distr., Yugorenok Setl. vicinity, Khlebny Creek, 7.IX.2000, coll. Ignatov s.n. (MHA); Far East: Vrangel Island, Western coast, 24.VIII.1987, coll. Afonina s.n. (LE); Chukotka Peninsula, Palyavaam River middle course, 9.VII.1989, coll. Afonina s.n. (LE); Kamchatkij Territory, Esso Settl. vicinity, 21.VIII.2003, coll. Czernyadjeva s.n. (LE).

MONGOLIA: Gobi-Altai Province, Gichgaenij Nuruu Mts, 7.VII.2001, coll. Ignatov \#01-827 (MHA).

\section{DISTRIBUTION OF ENCALYPTA SECT. RHABDOTHECA SPECIES IN RUSSIA}

\section{Encalypta rhaptocapra}

As it was previously stated by Savicz-Lyubitskaja \& Smirnova (1970) and by Horton (1983), Encalypta rhaptocarpa has an Arctic-alpine distribution, that includes most Subarctic territories and occasionally penetrates to more southern boreal areas, where rock outcrops are abundant, as well as to southern mountain regions (Fig. 4). It occurs in Karelia Republic, Murmansk and Archangel'sk Provinces, Komi Republic; in Ural Mts it penetrates southward to Perm Province. One specimen from Teberda, Caucasus, was also referred to this species. It is widespread throughout the Siberian mountains, excluding the most xeric southern areas (Transbaikalia) where E. pilifera predominantly grows. In the Far East E. rhaptocarpa occurs throughout the Chukotka Peninsula, and penetrates to the Kamchatka Peninsula, becoming rarer southwards. In Eastern Kamchatka it is mostly associated with outcrops of basaltoid lava, rich in Ca. An isolated population of the species is known on Sakhalin Island, where it is also associated with limestone outcrops. All specimens from the Middle Part of European Russia were referred to other species.

\section{Selected specimens examined:}

\section{NORWAY: Spitsbergen, KPABG \# 111387.}

RUSSIA: European Russia: Franz Josef Zemlya, Hooker's Island, Sedov Cape, 28.VII.1953, coll. Savicz s.n. (LE); Murmansk Province, Kirovsk Distr., Khibiny Mts, Yuksporlack Pass, 8.VIII.1948, coll. Schljakov \#2044a (LE); Karelia Republic, Paanajarvi, National Park, coll Maksimov \#Пaa-03/ 13-35(1) (PTZ); Arkhangel'sk Province, Pinega Distr., Pinezhskyj State Reserve, Moseev Nos Cape, 18.VII.2000, coll. Churakova \#750 (MW); Komi Republic, Troitsko-Pechorskij Distr., Pechoro-Ilychskij State Reserve, Kozhim River mouth vicinity, 13.VI.1962, coll. Nepomilueva s.n. (LE); Nenets Autono- 


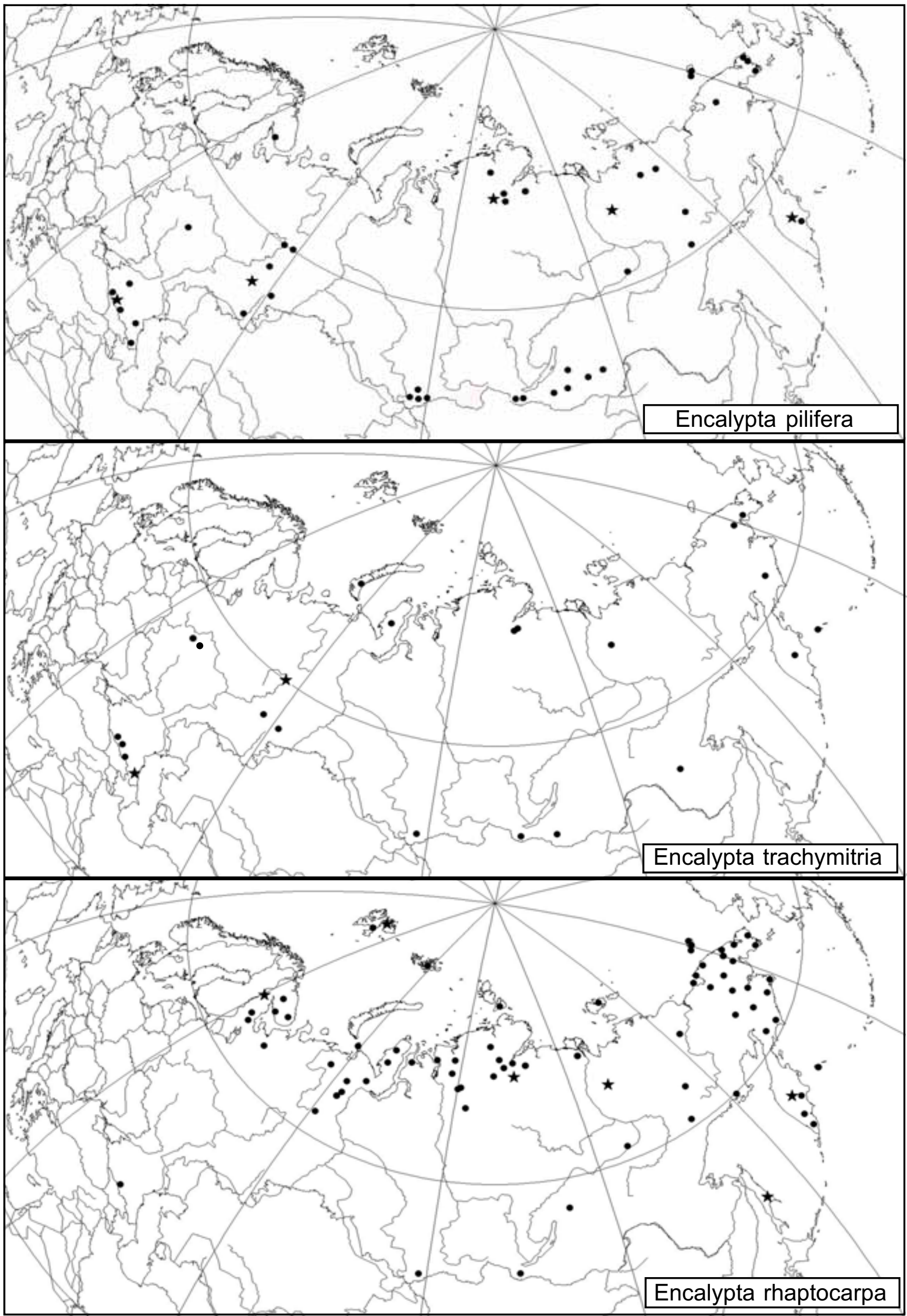




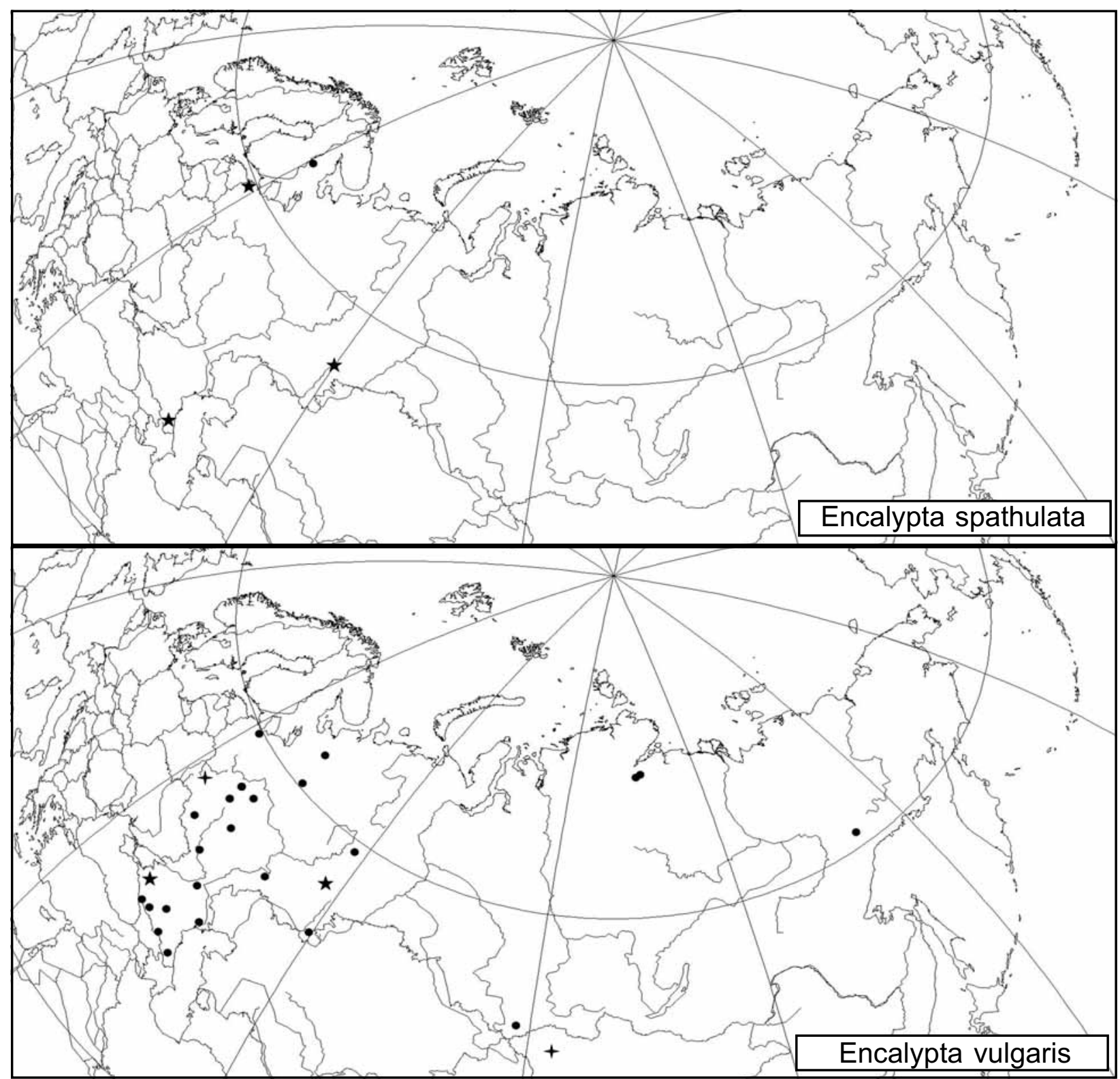

Fig 4 (see also p. 108). Distribution of species Encalypta sect. Rhabdotheca in Russia. Sequenced specimens are marked by star.

mous Distr., Vaygach Island, 5.VIII.2004, coll. Lavrinenko s.n. (LE); Urals: Polar Ural, Station $129^{\text {th }} \mathrm{km}$, middle course of Sob' River, VII.1988, coll. Czernyadjeva s.n. (LE); Perm Province, Krasnovisherskij Distr., Visherskyj State Reserve, Lypja River Valley, 12.VII.1995, coll. Bezgodov \#549 (MW); Caucasus: Karachaevo-Cherkessian Republic, Teberdinskyj State Reserve, VIII.1955, coll. Abramov \& Abramova \#1784 (LE); Siberia: Jamal Peninsula, Sabayaha River middle course, 26.VII.1992, coll. Czernyadjeva s.n. (LE); Gydan Peninsula, Chugor'-Yaha River lower course, 25.VII.1991, coll. Czernyadjeva s.n. (LE); Severnaja Zemlya Archipelago, Bol'shevik Island, 19.VIII.2000, coll. Matveeva s.n. (LE); Krasnojarsk Territory, Taimyrskyj Distr., Putorana Plateau, Ajan Lake vicinity, 1984, coll. Czernyadjeva s.n. (LE); Krasnojarsk Territory, Taimyrskyj Distr., Big Arctic Reserve, Biostation of Willem Barents, 28.VII.2002, coll. Varlygina s.n. (MW); Krasnojarsk Territory, Taimyrskyj Distr., Taimyrskyj State Reserve, Ledyanaja Bay vicinity, 23.VII.2004, coll. Fedosov \#Enc15 (MW);
Krasnojarsk Territory, Taimyrskyj Distr., Maymecha River valley, 1.VII.2009, coll. Fedosov \#09-470 (MW); Krasnojarsk Territory; Evenkija, Baykit Distr., Birobchana River lower course, 21.VII.1991, coll. Shcherbina s.n. (MW); Altai Republic, Altai Mts, Kuraiskij Range northward Kosh-Agach Settl., near the peak 2788 m, 1.VIII.1992, coll. Ignatov \#31/137 (MHA); Buryatia Republic, Tunkinskyj Distr., Vostochnye Sayany Mts, Arshanskyj Pass, 2.VIII.2007, coll. Seregin et. al. \#M-1968 (MW); Zabaikalsky Territory, Kalar Distr., Kodar Range near Leprindo Lake, 9.VIII.2012, coll. Afonina \#9112 (LE); Yakutia: Novosibirskie Ostrova Archipelago, northern Part, 28.VI.1902, coll. Birulya s.n. (LE); Lena River lower course, Kumachsur, 22.VII.1898, coll. Nilsson-Ehle s.n. (LE); Eveno-Bytantaiskij Distr., Batagay-Alyta, 28.VII.2011, coll. Ignatov \#11-4379 (MW); Oimyakon Distr., Agayakan Settl. vicinity, 10.VII.2011, coll. Ignatov \& Ignatova \#11-2324 (MW); Khangalasskij Distr., Lenskie Stolby, 17.VIII.2000, coll. Ignatov \#00-582 (MHA); Ust'-Maja Distr., Allakh-Yun Settl. vicinity, Tarbagannakh 
Creek upper cource, 25.VIII.2000, coll. Ignatov s.n. (MHA); Far East: Vrangel Island, Ushakovskyj Settl. vicinity, 23.VIII.1987, coll. Afonina s.n. (LE); Chukotka Peninsula, Ajon Island, 19.VII.1983, coll. Afonina s.n. (LE); Chukotka Peninsula, Palyavaam River middle course, 9.VII.1989, coll. Afonina s.n. (LE); Magadan Province, Ol'sky Distr., Pjagina Cape vicinity, 17.VIII.1978, coll. Blagodatskikh s.n. (LE); Kamchatkij Territory, Esso Settl. vicinity, 21.VIII.2003, coll. Czernyadjeva s.n. (LE); Kamchatskij Territory, Aleutskij Distr., Bering Island, 26.VIII.2010, coll. Fedosov \#10-3-84 (MW); Kamchatkij Territory, South Kamchatka, Hodutka Bay vicinity, 24.VII.2002, coll. Czernyadjeva \#23 (LE); Sakhalin Island, Smirnykh Distr., Vaida Mt. Nature Reserve, 20.VIII.2006, coll. Ignatov \& Teleganova \#06-234 (MHA).

\section{Encalypta spathulata}

Horton (1983) provides a map of $E$. spathulata world distribution, which demonstrates a clear west-western pattern according to Schofield (1988). Among localities of the species mentioned for Russia before (Ignatov et al., 2006), only the Karelian one is confirmed, while other studied specimens represent E. pilifera. Three more specimens, which fit well with the strict conception of the species, were found in the course of revision of herbarium collections. All these new localities are from European Russia, confirming the principally western distribution of the species, but extending its range up to the Ural Mountains (Fig. 4).

Selected specimens examined:

RUSSIA: European Russia: Karelia Republic, Suojarvi Distr., Suystamo Settl. vicinity, S'ajunjavaara Mt., 15.V.1936, coll. Huuskonen s.n. (H \#4061670); Pskov Province, Pechersky Distr., Izborsk, 19.X.1997, coll. Ignatov \& Zolotov s.n. (MHA); Urals: Chelyabinsk Province, Nyazepetrovskij Distr., Shemahinskaja-2 cave vicinity, 8.I.2012, coll. Ibatullin s.n. (MHA, MW); Caucasus: Dagestan Republic, Gunib Distr., Mountain Botanical Garden territory, 20.V.2009, coll. Ignatov \& Ignatova \#09-367 (MHA).

\section{Encalypta trachymitria}

The Russian distribution of E. trachymitria (Fig. 4) has a pattern similar to that of E. pilifera. It occurs in Arctic \& Subarctic and in more southern montane areas, being rare in most territories, but \pm frequent in the Caucasus and South and Middle Ural Mts, where almost all studied peristomate specimens represent this species. Only two localities in lowland European Russia are known.

\section{Selected specimens examined:}

RUSSIA: European Russia: Moscow Province, Odintsovo Distr., Zvenigorodskaja Biological Station vicinity, 27.VI.2004, coll. Sukhova s.n. (MW); Ryazan Province, Miloslavskoe Distr., Pryamoglyadovo, 5.V.2010, coll. Volosnova s.n. (MHA); Urals: Perm Province, Krasnovisherskij Distr., Visherskyj State Reserve, Vishera River Valley, 15.VI.1995, coll. Bezgodov \#141 (MW); Sverdlovsk Province, Nizhneserginskij Distr., Katnikovskaja cave vicinity, 21.V.2011, coll. Ibatullin s.n. (MHA, MW); Bashkortostan Republic, Duvanskij Distr., Gladkaja Mt. vicinity, 26.VI.2003, coll. Muldashev \#50 (MW); Caucasus: Kabardino-Balkarskaja Republic, Bezengy Gorge, 24.IX.2003, coll. Onipchenko s.n. (MW); Karachaevo-Cherkessian Republic, Teberdinskyj State Reserve,15.IX.2005, coll. Ignatov \& Ignatova \#05-1025 (MW); Severnaja Ossetia Re- public, North-Ossetian State Reserve, 25.VII.1979, coll. Abramova s.n. (MW); Dagestan Republic, Gunib Distr., Gunib Settlement vicinity, 19.V.2009, coll. Ignatov \& Ignatova \# 09-352 (MW); Siberia: Novaya Zemlja Archipelago, Chernaja Bay, LE; Yamal Peninsula, Erkutajaha River lower course, 28.VII.1994, coll. Czernyadjeva \#70 (LE); Krasnojarsk Territory, Taimyrskyj Distr., Odikhincha Mt., 14.VIII.2011, coll. Fedosov \#11-631 (MW); Altai Republic, Altai Mts between Kayra-Bashi Peak and Bardaky Lake, 14.VII.1991, Ignatov \# 13/124 (MHA); Burytia Republic, East Sayan Mts, valley of Sorok River, 9.VII.2008, Afonina s.n. (LE); Zabaikal'sky Territory, Agin-Buryat Autonomous Area, National Park Alkhanai, 9.VII.2006, coll. Afonina \# 2206 (LE;) Yakutia: Eveno-Bytantaisky Distr., Orulgan Range, Dzhelon Creek valley, 1.VIII.2011, coll. Ignatov \#11-3827 (MW); Far East: Chukotka Peninsula, Chegitun' River lower course, VIII.1991, coll. Afonina s.n. (LE); Kamchatskij Territory, Esso Settl. vicinity, 28.VII.2001, coll. Czernyadjeva s.n. (LE); Kamchatskij Territory, Aleutskij Distr., Bering Island, 5.VIII.2010, coll. Fedosov \#10-3-360 (MW); Amurskaja Province, Tukuringra Range, Zeiskij State Reserve, 24.VII.1989, coll. Petelin s.n. (MHA).

\section{Encalypta vulgaris}

The distribution of $E$. vulgaris in Russia is relatively wide in its European part (Fig. 4), where it is not rare in xeric southern areas and often occurs beyond their limits, penetrating to Leningrad and Archangel'sk Provinces. This is the only species of the studied section that occurs in the lowland of Middle European Russia northward from the steppe zone, excepting two localities of $E$. trachymitria in Moscow and Ryazan Provinces. Encalypta vulgaris turns out to be very rare eastward from the Urals, where only in the most xeric conditions of Siberia it occasionally occurs. This species was also referred for Chukotka by Afonina (2004), but all studied specimens were labeled E. vulgaris fo. pilifera and represent $E$. pilifera. On the eastern and western limits of its distribution in the observed area, in European Russia northward from the steppe zone and in the Altai Mts \& Mongolia, E. vulgaris intergrades with other species where some problematic specimens transitional to E. pilifera occur. Two such specimens, from Smolensk Province and Mongolia, were incorporated into the analysis with results shown on the trees and discussed above. Apparently it can form hybrids with other Encalypta species.

According to Horton's (1983) and our data, the world distribution of the species is associated with western parts of Eurasia and North America. So, it resembles the distribution of other xeric species, like Grimmia tergestina Tomm. ex Bruch at al., Aloina rigida (Hedw.) Limpr., Pterygoneurum subsessile (Brid.) Jur., Syntrichia caninervis Mitt., etc., demonstrating Circum-Thetian (Murray, 1992) or Circum-Mediterranean (Kürschner, 2008) pattern.

Selected specimens examined:

RUSSIA: European Russia: Arkhangel'sk Province, Pinezhskij State Reserve, 10.VIII.1988, coll. Ignatov s.n. (MHA); Leningrad Province, "Lava River canyon" protected area, 15.V.2005, coll. Ukrainskaja s.n. (LE); Smolensk Province, Sapsho Lake, 16.VII.2004, coll. Ignatov s.n. (MW); Moscow Province, Krasnogorsk Distr., Istra River bank, 16.VI.1986, coll. 
Ignatov s.n. (MHA); Ryazan Province, Miloslavskoe Distr., Pryamoglyadovo, 21.VI.2001, coll. Volosnova s.n. (MW); Vologda Province, Sukhona River bank upstream Sergeevskaja Settl., 15.VIII.2001, coll. Ignatov \& Ignatova s.n. (MHA); Kaluga Province, Dzerzhynsk Distr., Ugra National Park, Zvizha Settl. vicinity,a 20.V.2007, coll. Ignatov \& Teleganov \#07-307 (MHA); Lipetsk Province, Donskoj Distr. Bystraja Sosna River valley,15.VIII.1963, coll. Samsel'\#136(MW); Belgorod Province, Novooskol'skij Distr., Stenki-Izgorja Reserved Area, 12.V.1999, coll. Ignatov s.n. (MHA); Voronezh Province, Serdyuki Settl. vicinity, 23.IV.1983, coll. Popova s.n. (LE); Volgograd Province, Ilovlynskij Distr., Zmeinaja Mt., 10.VIII.1999, coll. Ignatov s.n. (MHA); Rostov Province, Myasnikovskij Distr., Nedvigovka Settl. vicinity, coll. Sereda 16.V.2005 (MHA); Kalmykia Republic, Ikiburul'sk Distr., Lola Settl. vicinity, 10.V.2010, coll. Ukrainskaja s.n. (LE); Astrakhan' Province, Bogdinsko-Baskunchakskij State Reserve, Bogdo Mt., 2.V.2002, coll. Suragina s.n. (MHA); Samara Province, Molodetskij Kurgan, 13.I.1910, coll. Anonym (LE); Orenburg Province, Kuvandykskij Distr., Orenburgskij State Reserve, 31.V.2004, coll. Zolotov \& Spirina s.n. (MHA); Urals: Perm' Province, $10 \mathrm{~km}$ southward Kungur Settl., Strizhevoy Boulder, 23.IX.1988, coll. Ignatov s.n. (MHA); Bashkortostan Republic, Sterlitamakskyj Distr., Shihan Yuractau, 15.VI.2010, coll. Baisheva \#837-1 (MW); Caucasus: Krasnodar Territory, Anapa Distr., Malyj Utrish Settl. vicinity, 4.V.2005, coll. Ignatov \& Ignatova \#05-9 (MW); Stavropol' Territory, Kislovodsk Town vicinity, 11.VI.1993, coll. Ukrainskaja \#13315 (LE); Karachaevo-Cherkessian Republic, Teberdinskyj State Reserve, 23.VIII. 1993, coll. Onipchenko \#89 (MW); Dagestan Republic, Leninkent Distr., Makhachkala vicinity, 17.V.2009, coll. Ignatov \& Ignatova \#09-20 (MW); Siberia: Krasnojarsk Territory, Taimyrskyj Distr., Anabar Plateau, Kotuykan River mouth vicinity, 11.VIII.2011, coll. Fedosov \#11-1150 (MW); Altai Republic, Karakem River valley, Kukol', 23.VI.1989, coll. Ignatov \#0/589 (MHA); Yakutia: Ust'-Maja Distr., Yugorenok Setl. vicinity, Shchel' Creek, 8.IX.2000, coll. Ignatov \#00-595 (MHA).

\section{DISCUSSION}

The TCS analysis reveals that species of Encalypta section Rhapdotheca (excepting E. spathulata) form a haplotype network where the ends are represented by $E$. rhabtocarpa, a species with the maximally developed perisome in the section, and an epiristomate species, $E$. pilifera, while E. trachymitria and E. vulgaris occupy a transitional position. This position for E. trachymitria with its partly reduced peristome is in good agreement with species morphology. Encalypta vulgaris specimens appeared to be heterogeneous, likely indicating possible hybridization events with other species of the section.

As many species of the genus (e.g. E. affinis R. Hedw., E. brevicolla, E. brevipes Schljakov, E. longicolla Bruch, E. procera Bruch) and the second genus of the family, Bryobrittonia, have arcto-alpine distribution, which is also the case of Encalypta rhaptocarpa, the evolution of the group can be assumed as expansion to xeric areas along with perisome reduction.

Similarly arcto-alpine or arcto-montane species of Tortula, like T. mucronifolia Schwägr., T. hoppeana (Schultz) Ochyra, mostly have peristome that is lacking in xerophytic groups like T. caucasica Lindb., T. acaulon (With.) R.H. Zander, etc. Similar examples can be seen in Pterygoneurum, Bryoerythrophyllum, Grimmia, Enthosthodon, etc.

The specialized eperistomate populations evolve to a number of species in southern fragmented mountains, e.g. E. armata, E. asperifolia, E. buxbaumioides, E. flowersiana, E. texana, E. tianschanica J.-C. Zhao, S. He \& Hu Ren-liang, E. tibetana Mitt. At the same time, most of lowland territory of Russia, and likely all northern Eurasia, includes only one widely distributed species, E. pilifera. This fact can be explained by a rather easy way for migration, especially in the end of the Glacial Period, when tundra-steppe vegetation covered most of the territory where forest now grows. The fragments of tundra-steppes in Mongolia and in permafrost areas of Siberia are now the places where E. pilifera is especially regularly occurring in a broad range of habitats.

\section{ACKNOWLEDGEMENTS}

I am greatly indebted to Anatolij I. Maksimov, Thomas Hallingbäck and the curator of $\mathrm{H}$ for specimen loan, to Lars Hedenäs for the photo of holotype of E. obovatifolia, to Alexei V. Troitskij and Irina A. Milyutina (A.N. Belozersky Institute of Physico-Chemical Biology, MSU) for help with laboratory work, to Elena A. Ignatova for preparing illustrations, Ekaterina Yu. Kuz'mina for help with literature, Michael S. Ignatov for fruitful discussion and Diana Horton for interest to manuscript and correcting English of the paper. The work was partly supported by RFBR \# 12-04-31211.

\section{LITERATURE CITED}

[AFONINA, O.M.] АФОНИНА О.М. 2004. Конспект флоры мхов Чукотки. - [Moss flora of Chukotka] СПб, БИН РАН [Sankt-Petersburg, Bot. Inst. RAS], $260 \mathrm{pp}$.

CAO, T. C. GAO \& D.G. HORTON 2001. Encalyptaceae. - In: Li, X.-j. \& M.R. Crosby (eds.). Moss flora of China. English version. Volume 2. Fissidentaceae-Ptychomitriaceae. Science Press Beijing \& Missouri Botanical Garden, St-Louis. 103-113.

CLEMENT, M., D. POSADA \& K. A. CRANDALL 2000. TCS: a computer program to estimate gene genealogies. - Molec. Ecol. 9: 16571659

FUNCK, H.K. 1819. Encalypta pilifera. - In: J.V. Sturm. Deutschlands Flora, Abtheilung II. Cryptogamie 17: 7-8 \& Fig. 14.5.

GARDINER, A., M. IGNATOV, S. HUTTUNEN \& A. TROITSKY 2005. On resurrection of the families Pseudoleskeaceae Schimp. and Pylaisiaceae Schimp. (Musci, Hypnales). - Taxon 54: 651-663.

GOLOBOFF, P.A. 1994. NONA: A Tree Searching Program. Program and documentation. - Argentina, Tucumán, published by the author.

HAGEN, I. 1910. Det Kongelige Norske videnskabers selskabs skrifter. Trondheim, $48 \mathrm{pp}$

HALLINGBÄCK, T. 2008. Encalyptaceae. - In: HALLINGB̈̈CK, T., N. LÖNNELL, H. WEIBULL, L. HEDENÄS, \& P. VON KNORRING. Nationalnyckeln till Sveriges flora och fauna. Bladmossor: Sköldmossor-blåtmossor. Bryophyta: Buxbaumia-Leucobtyum. ArtDatabanken, SLU, Uppsala, 54-72.

HORTON, D.G. 1979a. Encalypta vittiana sp. nov. and E. flowersiana sp. nov. from North America. - The Bryologist 82 (3): 368-381.

HORTON, D.G. 1979b. Encalypta spathulata: An addition to the moss flora of North America. - Lindbergia 5: 63-70. 
HORTON, D.G. 1982. A revision of the Encalyptaceae (Musci) with particular reference to the north American taxa Part I. $-J$. Hattori Bot. Lab. 53: 365-418.

HORTON, D.G. 1983. A revision of the Encalyptaceae (Musci) with particular reference to the north American taxa Part II. - J. Hattori Bot. Lab. 54: 353-532.

IGNATOV, M.S., O.M. AFONINA \& E.A. IGNATOVA (eds.) 2006. Checklist of mosses of East Europe and North Asia. - Arctoa 15: 1-130.

[IGNATOV, M.S. \& E.A. IGNATOVA] ИГНАTOB M.C., Е.A. ИГНАТОВА 2003. Флора мхов средней части европейской России. T. 1. - [Moss flora of the Middle European Russia. Vol. 1] M., KMK [Moscow, KMK]:1-608.

JURATZKA, J. \& J. MILDE 1870. Beitrag zur Moosflora des Orientes. Verhand. Zool.-Bot. Gesellschaft Wien 20: 589-602.

KÜRSCHNER, H. 2008. Biogeography of South-West Asian Bryophytes - with special emphasis on the tropical element. - Turk. J. Bot. 32: 433-446.

LAWTON, E. 1971. Moss Flora of the Pacific Northwest. - Hattori Bot. Lab., Nichinan, Japan. $362 \mathrm{pp}$.

LIMPRICHT, K.G. 1895. Die Laubmoose. - In: Rabenhorst, L. Kryptogamen-flora von Duetschland, Oesterreich und der Scheiz. Bd. 3: 1-448.

MAGILL, R.E. 2006. A new species Encalypta (Encalyptaceae) from west Texas. - The Bryologist 109: 398-400.
MAGILL, R.E. 2007. Encalyptaceae. - In: Flora of North America. Vol. 27. Mosses, part. 1. New York, Oxford, Oxford Univ. Press: 170-179.

MOGENSEN, G.S. 2001. Encalypta rhaptocarpa Schwaegr and E. leptodon Lindb. in Denmark are E. trachymitria Rip.: on their taxonomy and differences (Bryophyta, Musci). - Lindbergia 26: 33-36.

MURRAY, B. 1992. Bryophyte flora of Alaskan steppes. - Bryobrothera 1: 9-33.

NIXON, K.C. 1999a. Winclada (BETA) ver. 0.9.9. available at http:// www.cladistics.com/about winc.html.

NIXON, K.C. 1999b. The parsimony ratchet, a new method for rapid parsimony analysis. - Cladistics 15: 407-414.

NYHOLM, E. 1995 (1996). A new species of Encalypta. - Lindbergia 20: $83-84$.

PODPERA, J. 1954. Conspectus Muscorum Europaeorum. - Praha, Nakladatelstvi Cesk. Akad. Ved., 699 pp.

[SAVICZ-LYUBITSKAYA, L.I. \& Z.N. SMIRNOVA] САВИЧЛЮБИЦКАЯ Л.И., З.Н. СМИРНОВА 1970. Определитель листостебельным мхов СССР. Верхоплодные мхи. - [Handbook of mosses of USSR. The acrocarpous mosses] Л., Наука [Leningrad, Nauka], $822 \mathrm{pp}$.

SCHOFIELD, W.B. 1988. Bryophyte disjunction in Northern Hemisphere: Europe and North America - Bot. J. Linn. Soc. 98(3): 211-224.

Table 2. Encalypta specimens used in the molecular analysis and GenBank accession numbers for trnL sequences

Species Specimen data

rhaptocarpa

rhaptocarpa

rhaptocarpa

rhaptocarpa

rhaptocarpa

rhaptocarpa

trachymitria

trachymitria

spathulata

spathulata

spathulata

pilifera

pilifera

pilifera

pilifera

pilifera

vulgaris

vulgaris

vulgaris

vulgaris

21.VIII.2003 (LE)
Russia, Kamchatka Peninsula, Esso Settl. vicinity, coll. Czernyadjeva 21.VIII.2003 (LE)

Russia, Karelia Republic, Paanajarvi, coll. Maksimov, \#Пaa-03/13-35(1) (PTZ)

Norway, Svalbard, coll. Belkina, \# 111387 (KPABG)

Russia, Yakutia Republic, Orulgan Range, coll. Ignatov \#11-4294a (MHA)

Russia, Krasnoyarskij Territory, Anabar Plateau, coll. Fedosov \#09-470 (MW)

Russia, Sakhalin Island, coll. Ignatov \& Teleganova \#06-234 (MHA)

Russia, Dagestan Republic, coll. Abakarova 27.VII.2011 (MHA)

Russia, Ural Mts., Sverdlovsk Province, coll. Ibatullin 21.V.2011 (MW)

Russia, Pskov Province, coll. Ignatov \& Zolotov 19.X.1997 (MHA)

Russia, Dagestan Republic, coll. Ignatov \& Ignatova, \#09-367 (MHA)

Russia, Ural Mts., Chelyabinsk Province, coll. Ibatullin 8.I.2012 (MW)

Russia, Krasnojarskij Territory, Anabar Plateau, coll. Fedosov, \# 09-234 (MW)

Russia, Kamchatka Peninsula, Esso Settl. vicinity, coll. Czernyadjeva

Russia, Caucasus Mts., Teberdinskij Reserve, coll. Ignatov \& Ignatova, \#05-3784 (MHA)

Russia, Bashkiria Republic, coll. Baisheva, \# 02-47 (MHA)

Russia, Yakutia Republic, Orulgan Range, coll. Ignatov, \#11-4058 (MHA)

Russia, Smolensk Province, coll. Ignatov 16.VII.2004 (MHA)

Russia, Rostov Province, coll. Sereda 16.V.2005 (MHA)

Russia, Bashkiria Republic, coll. Baisheva, \#837-1 (MW)

Mongolia, coll. Ignatov, \#01-833 (MHA)
GenBank

TSC

accession number

JX971199

JX971200

R4

JX971201

JX971202

JX971203

JX971204

JX971205

JX971206

JX971207

JX971208

JX971209

JX971210

JX971211

JX971212

JX971213

JX971214

JX971215

JX971216

JX971217

JX971218
R5

R6

R3

R1

R2

$\mathrm{T} 1$

$\mathrm{T} 2$

S2

S3

S1

P2

P5

P4

P3

P1

V3

V1

V2

V4

Sequences borrowed from GenBank: E. ciliata AF229897; E. rhaptocarpa AF023717; E. streptocarpa HM148898; E. vulgaris (France) EU128000. 